\title{
A case of combined congenital anterior and posterior arch anomaly of $\mathrm{C} 1$ vertebra
}

\author{
C1 vertebranın kombine konjenital anterior ve posterior arkus anomalisi olgusu
}

Onur Levent ULUSOY, Hadi SASANI, Ayhan MUTLU, Eray DARICI, Mustafa ŞİRVANCI

\begin{abstract}
A very rare case of the craniovertebral junction (CVJ) anomaly is reported owing to its rarity and clinical significance. Computed tomography (CT) and magnetic resonance imaging (MRI) studies of the cervical spine of a 56 -year-old female patient presented with head trauma, revealed an anterior midline arch cleft of atlas with totally aplastic posterior neural arch, as well as anteriorly subluxed right atlantoaxial joint. The coexistence of a total aplasia of the posterior neural arch and anterior arch cleft of atlas is very rare. Congenital anomalies affecting the craniovertebral junction (CVJ) may mimic traumatic injury in the setting of a previous trauma. In this presented case, the absence of an associated bone and soft-tissue edema on the MR imagings helped us to make a differention between the acute traumatic injury and congenital anomaly.
\end{abstract}

Keywords: Cervical Atlas, Magnetic Resonance Imaging, X-Ray Computed Tomography

\section{ÖZ}

Elli altı yaşında kadın hastanın kafa travması nedeniyle yapılan servikal vertebra bilgisayarlı tomografi ve manyetik rezonans görültemesinde (MRG), atlas anterior orta-hat arkus klefti ile total aplastik posterior nöral arkus ve anterior sublükse sağ atlantoaksiyel eklem saptand1. Posterior nöral arkusun total aplazisi ve atlasin anterior arkus kleftinin birlikteliği çok nadirdir. Kraniovertebral bileşkeyi etkileyen konjenital anomaliler, travma zemininde travmatik hasarı taklit edebilir. Bu olguda, akut yaralanma ve konjenital anomali arasındaki ayırımı yapabilmemizi non-invazif bir yöntem olan MRG sonuçlarındaki kemik ve yumuşak doku ödemi yokluğunun değerlendirilmesi mümkün kılmıştır.

Anahtar kelimeler: Servikal Atlas, Manyetik Rezonans Görüntüleme, Bilgisayarlı Tomografi.

Onur Levent Ulusoy ( $\varangle$ ), Ayhan Mutlu, Mustafa Şirvancı

Radiology Department, Florence Nightingale Hospital, Istanbul, Turkey

e-mail:ulusoyolevent@gmail.com

Hadi Sasani

Department of Radiology, Faculty of Medicine, Near East University, Nicosia, Northern Cyprus

Eray Darıc1

Baku Clinic, Department of Radiology, Baku, Azerbaijan

Submitted / Gönderilme: 16.10.2016

Accepted/Kabul: 13.12 .2016

\section{Introduction}

Congenital clefts and aplasias of the $\mathrm{C} 1$ vertebra are rare. These anomalies develop in intrauterine life as a result of developmental failure of chondrogenesis which may variate from partial clefts to total agenesis of the atlas rings [1-3]. In patients with a history of trauma, these anomalies can mimic an injury of the craniovertebral junction (CVJ) [1,4].

We present a case with traumatic craniofacial injury which has a rare association of congenital anterior and posterior arch anomaly of $\mathrm{C} 1$ and coexist with an unilateral anterior atlantoaxial joint subluxation that was initially thought to be post-traumatic.

\section{Case Report}

A 56-year-old female, who had accidentaly fell down was admitted with head trauma. An urgent cranial computed tomography (CT) scan showed minor right frontotemporalzygomatic superficial haemorrhage, and more caudal images of cranial CT depicted an abnormal atlas. At the time of admission, physical examination revealed no pathological findings with a full range of cervical movement and a normal neurological status. All laboratory investigations showed normal values. Due to the better demonstration of CVJ, a CT scan of the cervical spine was then performed. Total aplasia of posterior arch and midline cleft of the anterior arch of atlas were detected. There was partially anterior subluxation of right lateral mass of atlas over axis (Fig. 1,2). The pre-vertebral soft tissue at the upper cervical spine was not thickened (measuring about $4.9 \mathrm{~mm}$ at the $\mathrm{C} 2$ level on the mid-sagittal multiplanar reformat image). The distance between dens and atlas was measured $3 \mathrm{~mm}$ as normal. The rest of the cervical spine 


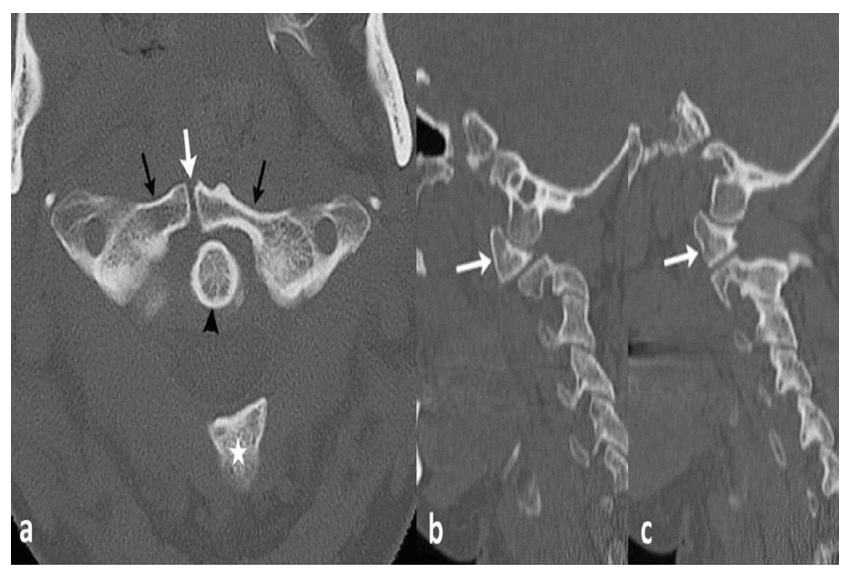

Fig.1 (a) Axial CT image shows anterior arch cleft (white arrow) and absence of entire posterior arch of $\mathrm{C} 1$, anterior hemiarches of atlas (black arrows), dens (arrow head) and prominent posterior tubercle (star) of C2. (b,c) Sagittal multiplanar reconstruction CT images demonstrate right (b) and left (c) lateral masses of C1 (white arrows), and show anterior subluxation of the lateral mass of $\mathrm{C} 1$ over $\mathrm{C} 2$ on the right.

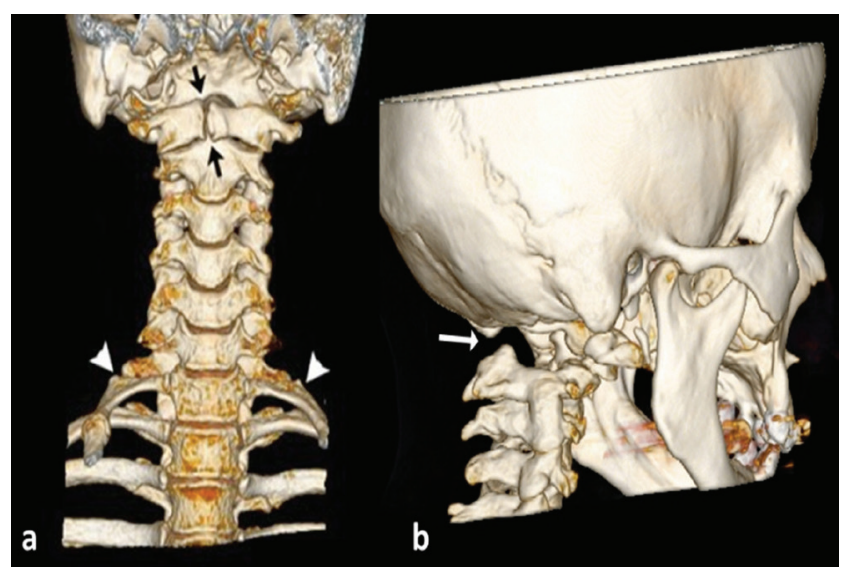

Fig. 2 (a,b) 3D volume rendering images show anterior arch cleft of $\mathrm{C} 1$ (black arrows), bilateral cervical ribs (arrow heads), absence of $\mathrm{C} 1$ posterior arch (white arrow).

seemed to be undisrupted. CT scan also revealed bilateral cervical ribs (Fig. 2). In view of the head trauma, a traumatic subluxation at the atlantoaxial joint was suspected. Magnetic resonance imaging (MRI) with a limited scan protocol [sagittal and coronal short tau inversion recovery (STIR)] was performed for clearance of cervical spine for occult fracture and also for demonstration of neural tissue at craniovertebral junction (Fig. 3). On MRI, there was no bony edema and there was neither fluid nor edema in/or around the subluxed right atlantoaxial joint. This indicated that the finding was not acutely caused by recent trauma. Lateral flexion/extension plain radiographs of the cervical

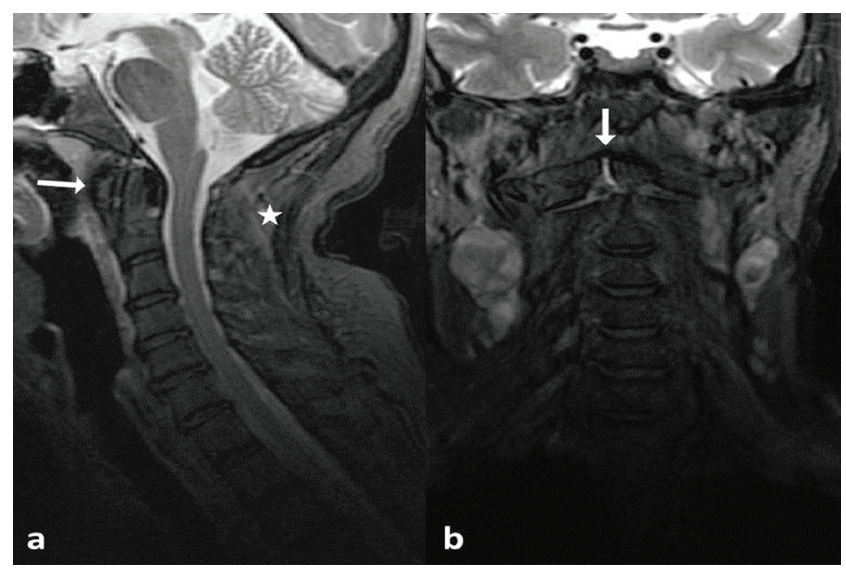

Fig. 3 (a) Sagittal STIR image depicts a normal anatomical relationship between atlas, dens and clivus (white arrow), a normal spinal canal and spinal cord, absence of the posterior arch (star) of C1. (b) Coronal STIR image shows an anterior arch cleft of $\mathrm{C} 1$ (white arrow), no bone or soft tissue edema at $\mathrm{CVJ}$ region including right atlantoaxial joint.

spine excluded atlantoaxial instability. Patient's clinical situation was stable and treated conservatively for the post traumatic craniofacial soft tissue injury. She remains well at follow up and, currently, has no complaints or symptoms.

\section{Discussion}

Congenital defects of the arches of $\mathrm{C} 1$ vertebra are rare anomalies and usually discovered incidentally. To have a detailed knowledge about embryological development is crucial to understand congenital atlas arch defects. A normal $\mathrm{C} 1$ vertebra can be divided into three parts including the anterior arch, the lateral masses, and the posterior arch. Three primary ossifications are responsible in formation of its parts including: an anterior ossification center which forms the anterior tubercle and two lateral centers which form the lateral masses and the posterior arch. In the seventh week of intrauterine life, ossification centers at the lateral masses extend posteromedially to form the posterior arch. A secondary center of ossification center which is the center for the posterior tubercle, may be present in about $2 \%$ of cases. Failure in any step of this complex process leads to abnormalities $[1,3,4]$.

Currarino et al. classified the posterior arch anomalies into five types depending on the absence of the posterior arch, the presence or absence of the posterior tubercle, and its clinical findings [1] (Table I). Based on the literature, 
Table I: Classification of the posterior arch anomalies [1]

\begin{tabular}{|l|l|}
\hline \multirow{5}{*}{ Types } & $\begin{array}{l}\text { Type A : Median clefts of the posterior arch of C1 (represent 97\% of all posterior arch defects) } \\
\text { Type B : Unilateral clefts } \\
\text { Type C : Bilateral defects } \\
\text { Type D : Complete absence of the posterior arch with a persistent isolated tubercle } \\
\text { Type E : Complete absence of the entire posterior arch } \\
\text { (Type A 4\%, Type B-E 0.69\%) }\end{array}$ \\
\hline Clinical groups & $\begin{array}{l}\text { 1) Asymptomatic incidental findings } \\
\text { 2) Neck pain or stiffness after trauma to the head or neck } \\
\text { 3) Chronic symptoms referable to the neck } \\
\text { 4) Various chronic neurological problems } \\
\text { 5) Acute neurological symptoms after minor cervical trauma }\end{array}$ \\
\hline
\end{tabular}

roughly $4 \%$ of patients present with congenital posterior arch defects, with the predominant (97\%) type being Type A $[1,4,5]$. Type B through Type E congenital defects have been reported to occur in $0.69 \%$ of the population [1]. Type E defects are very rare. One study found two patients $(0.18 \%)$ [3], while two studies did not find any patients with Type E defects and had patient populations of 1069 and 1153 respectively [4,5]. There have only been sporadic case reports of patients with Type E posterior arch anomalies. Anterior arch anomalies are much more uncommon than the posterior arch anomalies, and the reported incidence of the anterior arch anomalies is $0.1 \%$ $[1,4,6,7]$. The association of anterior and posterior arch defects, called a bipartite atlas, has been described in some studies [5,7]. Our case, may be classified as Type E and clinical subgroup 1, according to Currarino's classification of posterior arch and coexistent with anterior arch midline cleft anomaly [1].

Craniovertebral junction anomalies are commonly asymptomatic and found incidentally. When symptomatic, the symptoms typically begin insidiously and arise late, progress slowly, remain constant, and rarely relapse. The signs and symptoms of CVJ anomalies may be related to cervical spinal cord, the brain stem, cerebellum, cervical nerve roots, lower cranial nerves, or the vascular supply to these structures $[1,3-5,8]$. Our patient had no complaints or symptoms for detected $\mathrm{C} 1$ anomaly and, as in most cases reported in the literature, the anomaly was discovered incidentally by radiologic imaging after a trauma.
Posterior arch anomalies may be accompanied by other abnormalities, including clefts of the anterior arch, anterior atlantoaxial subluxation, rotatory atlantoaxial subluxation and cervical myelopathy are reported in the literature [1]. In our case, posterior arch anomaly of atlas exists together with both anterior arch cleft and anteriorly subluxed right atlantoaxial joint, and additionally with bilateral cervical ribs.

Imaging remains the first option for the evaluation of the patients and congenital anomalies of the CVJ are common incidental findings on cervical plain radiography. These anomalies should be kept in mind to avoid misinterpretation as fractures, luxation or osteolysis. Cervical lateral plain radiography with flexion and extension view may help to detect cases with instability where there is increased risk of spinal cord injury. CT is able to depict the nonossified and ossified portions of the arches of atlas (Fig. 1). It is especially useful for evaluating the integrity of the atlas rings, differentiating injury from a developmental cleft and demonstrating a small defect in the arch [1]. Additionally, CT with 3D reconstruction might display the topography of the upper cervical spine better, especially to clinicians (Fig. 2). Although, MRI is inadequate for diagnosing because of the lack of magnetic resonance signal from cortical bones, but osseous and/ or periosseous soft tissue edema is easily visible and an important finding as indicating trauma or inflammation, thus making MRI a valuable tool for differentiating acute traumatic spinal lesions from other congenital and acquired abnormalities [9]. Furthermore, MRI study has advantages in evaluating the spinal cord, adjacent neural 
structures and paraspinal soft tissue to exclude or confirm extraosseous causes of clinical symptoms $[1,2,5,9]$. Our patient was diagnosed coincidentally in the setting of an acute trauma, while anomaly was easily detected by CT and MRI showing no signal alteration neither in bone nor in the joints as well as no soft tissue edema at the region of CVJ and no cord compression and/or signs of myelopathy (Fig. 3). This indicated that the findings, especially subluxed right atlantoaxial joint, was not acutely caused by recent trauma. It is thought to be nontraumatic chronic subluxation due to the existing congenital anomaly.

Surgery is the treatment of choice in symptomatic patients [10]. CVJ anomalies in patients with history of trauma, the possibility of spinal cord injury should always be considered. Neurological symptoms may become symptomatic after minor cervical trauma in patients with this anomaly [8]. For the current patient, since there was no symptoms due to this congential anomaly, and there was no clinical and radiological sign of atlantoaxial or occipitocervical instability, the decision was made not to undergo for any non-surgical and surgical management. However, in such patients with this anomaly, it is recommended to avoid contact sports.

In this presented case, it was possible to evaluate the absence of associated soft-tissue and bone marrow edema by using MRI, which allowed non-invasive differentiation between the cases of acute injury and congenital anomaly. When upper cervical spine anomalies are found in a patient with acute trauma, the patient should be evaluated in detail with $\mathrm{CT}$ and MRI for avoiding misinterpretation as fractures, traumatic luxation, or instability. Advanced radiological studies could help making accurate diagnosis and deciding on therapeutic methods.

\section{References}

1. Currarino G, Rollins N, Diehl JT. Congenital defects of the posterior arch of the atlas: a report of seven cases including an affected mother and son. Am J Neuroradiol 1994;15:24954.

2. Klimo P Jr, Blumenthal DT, Couldwell WT. Congenital partial aplasia of the posterior arch of the atlas causing myelopathy: case report and review of the literature. Spine 2003;28:E224-28. doi: 10.1097/01.BRS.0000065492.85852. A9.

3. Senoglu M, Safavi-Abbasi S, Theodore N, Bambakidis NC, Crawford NR, Sonntag VKH. The frequency and clinical significance of congenital defects of the posterior and anterior arch of the atlas. J Neurosurg Spine 2007;7:399-402. doi: 10.3171/SPI-07/10/399.

4. Kwon JK, Kim MS, Lee GJ. The incidence and clinical implications of congenital defects of atlantal arch. J Korean Neurosurg Soc 2009;46:522-27. doi: 10.3340/ jkns.2009.46.6.522.

5. Pasku D, Katonis P, Karantanas A, Hadjipavlou A. Congenital posterior atlas defect associated with anterior rachischisis and early cervical degenerative disc disease: a case study and review of the literature. Acta Orthop Belg 2007;73:282-85.

6. Guenkel S, Schlaepfer S, Gordic S, Wanner GA, Simmen HP, Werner CM. Incidence and variants of posterior arch defects of the atlas vertebra. Radiol Res Pract 2013:957280. doi: $10.1155 / 2013 / 957280$.

7. Prempe RC, Gibson JC, Bhattacharya JJ. Mid-line clefts of the atlas: a diagnostic dilemma. Spinal Cord 2002;40:92-93.

8. Torreman M, Verhagen IT, Sluzewski M, Kok AJ, van Rooij WJ. Recurrent transient quadriparesis after minor cervical trauma associated with bilateral partial agenesis of the posterior arch of the atlas. Case report. J Neurosurg 1996;84:663-65.doi: 10.3171/jns.1996.84.4.0663.

9. Dundamadappa SK, Cauley KA. MR imaging of acute cervical spinal ligamentous and soft tissue trauma. Emerg Radiol 2012;19:277-86. doi: 10.1007/s10140-012-1033-4.

10. Choi JW, Jeong JH, Moon SM, Hwang HS. Congenital cleft of anterior arch and partial aplasia of the posterior arch of the C1. J Korean Neurosurg Soc 2011;49:178-81. doi: 10.3340/ jkns.2011.49.3.178. 